\title{
Pro-Social and Altruistic Behaviors of Military Students in Random Events
}

\author{
Marek Bodziany $^{1}$ (D) Ryszard Kałużny $^{2}$ (D)
}

Accepted: 19 January 2021 / Published online: 3 February 2021

(c) The Author(s), under exclusive licence to Springer Nature B.V. part of Springer Nature 2021

\begin{abstract}
The cognitive purpose of the research presented in the article is to identify the propensity for pro-social and altruistic behavior among first-year military students (of basic training) in three simulated situations of need for help to other people. It raised the question contained in the main research problem: to what extent do military students at universities tend to behave in a pro-social and altruistic way in situations that pose a threat to the other people's life and health, and what is the relationship between these behaviors and socialization in the civil environment? At the outset, the hypothesis was adopted that the candidates for professional soldiers show (or at least should show) a higher propensity for this type of behavior. For its verification, the population of the first-year military students during their basic training was assumed as a research area. The study covered 246 people ( 85 women and 161 men) selected randomly from among military students in the first year of studies of the command profile (major in management and command studies) of all military specialties and the medical profile. The selection of the research sample based on first-year students during the basic training ( 1 month of service) aimed to identify the impact of environmental factors (primary and secondary socialization as a "civilian") on the tendency to altruistic and prosocial behavior in two different groups of candidates for professional soldiers.
\end{abstract}

Keywords Ethics $\cdot$ Pro-social activities $\cdot$ Altruism $\cdot$ Courage $\cdot$ Heroism

\section{Introduction}

Soldiers' pro-social and altruistic behaviors is a crucial subject for two reasons. The first one is the professional specificity, a service based on autotelic values inscribed in the organizational culture. The second reason is related to the first one, but apart from

Marek Bodziany

m.bodziany@interia.pl

Ryszard Kałużny

ryszard.kaluzny@awl.edu.pl

1 Faculty of Security Sciences, Military University of Land Forces, Publishing House of AWL, Wroclaw, Poland

2 Faculty of Management, Military University of Land Forces, University of Lower Silesia, Wroclaw, Poland 
the axiological dimension, it refers to the soldiers' constitutional duties as guarantors of multidimensional security for all social groups that contribute to the national social system. That applies not so much to the soldier's professional obligation as to the natural and internal need to help people in every situation. Given the issues raised, it should be assumed that military universities, apart from their educational function, are institutions building an individual axio-normative order of candidates for professional soldiers. It is primarily aimed at shaping pro-social and altruistic attitudes. Their practical dimension manifests itself in many initiatives launched by the students to assist people in various random situations, including emergencies.

Although the range of such initiatives is extensive, the most visible are the students' prosocial behavior during the first wave of the COVID-19 crown pandemic. They had not only an institutional but also an individual dimension. One of the pro-social actions was the anticrisis operation organized with the Territorial Defense Forces soldiers under the code name "Resilient Spring" that involved almost 500 military students. Besides, they also took part in other initiatives for the benefit of society, including the delivery of food, medicine, and other necessary materials and products, support for veterans, material support for people in quarantine and veterans of overseas operations, the elderly, the disabled, and single parents. A fundamental element of the pro-social campaign carried out by AWL military students during the pandemic was the blood donation campaign on March 19-May 25, 2020, thanks to which $180.65 \mathrm{~L}$ of blood were collected. Also, five aid campaigns for hospices and assistance for the St. Brother Albert for Homeless Women were initiated (Bodziany, 2021).

Two classical perspectives were used as a theoretical basis for researching the behavior of military students in circumstances of random events. The first one concerns prosocial, while the second one refers to altruistic behavior, whose formal framework is found in the "Code of Honor of a Polish Soldier" (Polish: Kodeks Honorowy Żołnierza Wojska Polskie-go, KHŻWP). The provisions contained in the introduction to the aforementioned document are essential for examining this type of activity. There we read: "Professional soldiers perform military service for the benefit of the Republic of Poland. This service requires discipline, loyalty, and sacrifice. The semantic key of the analysis is the word "sacrifice", which is the basis of the fundamental virtues contained in the chapter entitled "Dignity and honor of a professional soldier." These include patriotism, valor, honesty, responsibility, justice, truthfulness, and professional solidarity. The most important provisions for the analysis of the relationship between the specificity of the profession and the type of behavior are contained in the chapter entitled "Dignity and honor of a professional soldier": "A professional soldier out-side the service." They sound as follows: "He or she is not indifferent to negative attitudes and actions. He or she helps those in need and acts in defense of the victims" (KHŻWP). Accepting these records as a cultural canon of a total, relatively closed and formalized organization (Davies, 1989, pp. 77-95; more: Goffman, 1975), it should be assumed that pro-social and altruistic behaviors among soldiers (and candidates for soldiers) are more characterized by a clear, descriptive relationship than in the case of other, particularly non-uniformed, professional groups. For the study, however, the assumption was made that candidates for professional soldiers in the first year of service (basic training-lasting about one month of service) have a different set of pro-social values than candidates in higher years of service. That is due to the short period of adaptation to service and the limited military experience. It means that the research concerned the propensity for such behaviors based on environmental factors shaping their values within primary and secondary socialization and through an upbringing in the family and school. A question arose from the adopted assumptions that concerned 
the propensity of candidates for professional soldiers to devotion, sacrifice, heroism, and disinterestedness. They shaped socially and culturally in a diverse "civil" environment, in the reality of ubiquitous consumption, and the growing prevalence of instrumental values over autotelic ones.

As already underlined, the theoretical basis of the research was the theory of prosocial behavior, the sine qua non of which is the fulfillment of the following conditions: recognition of a (someone else's) need, recognition that this need can be met, recognition of one's own responsibility, and assessment of the costs of assistance. In emergencies, it is reduced practically to a minimum through an impulsive reaction. It means violent, resulting from the influence of socialization and upbringing from the past, the compulsion to respond when facing a random event, a disaster, or a tragedy. Many authors have written about environmental factors of pro-social behavior. Particularly noteworthy are the reflections of Daniel Batson and his co-authors, whose interests have focused on the etiology of prosocial behavior, including empathy. (Batson et al., 1995, pp. 619-631; Batson \& Ahmad, 2009; Batson \& Powell, 2003, pp. 463-484).

Sources of pro-social as well as altruistic behavior have contributed to not only Badson's but also many other authors' scientific investigations. The analysis of the literature leads to explicating the following ones: empathy — an emotional state induced by the situation of another person, internalization (assimilation) of norms dictating acting on behalf of others, such as the norm of reciprocity, the norm of love for people, the norm of social responsibility, as well as building personal bonds, for example, friendship and sympathy, and treating another person as an autonomous value (more: Batson \& Shaw, 1991, pp. 107-122; Kaur, 2019, pp. 227-229). Apart from the factors mentioned above, a sense of bond with other people is also mentioned, which can be felt towards people (in smaller or larger social groups). It should be stressed that pro-social behavior is also associated with general personality traits such as honesty, humility, amicability, as well as, appearing in most studies, empathy, and orientation towards others (Penner et al., 2005, pp. 365-392; Eisenberg \& Fabes, 1990, pp. 131-149). The article written by Samuel Quain and others, entitled "Pro-Social Behavior amongst Students of Tertiary Institutions: An Explorative and a Quantitative Approach" (Quain, Yidana et. al. 2016), developed from student-based research, constituted the basis for the comparison of his research findings with those of others. The study highlights the environmental implications of a propensity for pro-social behavior depending on age (student population), gender, and social background.

As for altruism, it should be stressed that is "[...] is one of the most important moral virtues that is worth striving for in the upbringing of children and young people. It is a virtue (or value) considered fundamental and universal (Łobocki, 2006, p. 108). The need to develop al-truism in the process of upbringing is penetrated by the fact that it is not only a counterbalance to various anti-social behaviors and attitudes but also a need to shape proper interpersonal inter-actions, especially in a society based on technology and information, in which the loss of ordinary interpersonal relations is becoming increasingly evident (Łobocki, 1999, p. 30). Taking Blechman's definition of altruism as an interpretative framework for the concept describes altruism as "unselfish behavior to promote the good of others despite harming oneself" (2002, p. 23), this phenomenon should be seen in terms of its integrity with pro-social activities. For without altruism shaped "in itself," a human would not be able to act selflessly on behalf of another person or even an institution. Regardless of the definition, altruism reveals all desirable characteristics for such a specific institution as the Armed Forces. The requirements placed on soldiers described not only in the codes of honor of various armed forces but also in the regulations and instructions, give altruism an institutional character. That is underpinned by the need to 
shape disinterestedness, cooperation, and mutual assistance, which are essential in military action and beyond. That means that altruism (although not literally) is or at least should be a feature of every soldier. It also results from the mere availability to the public and the constitutional duties of the state.

It is imperative for our research to establish a framework for interpreting the qualities that are even indispensable in the soldier's profession (service), including courage and heroism. Together with traditions and history, they form a knightly ethos, as a catechism set at the top of the hierarchy of values of the axio-normative order of the Armed Forces (more: Wardzała-Kordyś \& Bodziany, 2012, pp. 264-261). On this ground, an interpretative dilemma related to the fundamental question of who can be qualified as a hero arises. Zenon W. Dudek presents a hero as "[...] an exceptional character, breaking out of collective rights; an original, strong and, expressive individuality [...]" (Dudek, 2007, p. 10). The essence of heroism is not revealed in the form of heroic morality but as an effect of heroic action. Following this reflection, "...a person who, whether by overcoming natural fear or without special effort, performs acts beyond the bounds of duty [...] heroism is not an obligation and cannot be required from all people to act like heroes" can be called a hero (Pybus, 1982, p. 193). Thus, heroism is an unusual phenomenon that impacts social awareness. On the other hand, a hero is usually coded in social perception as a person with above-average, even supernatural qualities, and skills (New, 1974, p. 181). It is worth emphasizing that "[...] heroism is a factor that influences the other members of a given nation and not only them, while human heroism has a nation-building character in a double dimension: firstly, it is a model and the strengthening for those who participate in the same culture. Secondly, it is a challenge to encourage those who live next to it (Tarasiewicz, 2010, p. 55). A hero also plays the culturally creative role of a model to follow, and his/her image is described by two related characteristics, namely heroism and virtue. That is justified by several approaches, which reveal the thesis that the more a person respects moral principles, acts according to socially shaped patterns, and is guided by rational thinking, the less heroic, and thus less capable of heroic actions, and vice versa, he or she is. (Bodziany, 2019, p. 64). Heroism and virtue are "unity"—a coherent whole embedded in traditional moral philosophy. It is the domain of exceptional people whose actions do not expect applause, praise, or rewards, and above all, the heroes treat heroic deeds as a duty (Annas, 2015). According to J. O. Urmson, the creator of the concept of sovereignty, such a claim is an act of "false modesty." The author also considers virtue in combination with heroism as holiness, but it is not the frequency of deeds that matters, but their sources (Chopra, 1963). The essence of heroism understood as a virtue is expressed in words: "Heroism represents the ideal of citizens transforming civic virtue into the highest form of civic action, accepting either physical peril or social sacrifice" (9; Franco et al., 2016, 337). Except for the authors cited, the works relating to heroism and virtue of such researchers as Muel Kaptein (2008) and Goethals and Allison (2012) are also noteworthy.

The pro-social and altruistic, and at the same time heroic behaviors are all manifestations of actions aimed at helping people in a life-threatening or healththreatening situation. The results of research informing about whether to help people or not in various life or health threatening situations can be considered as an objective indicator to assess the pro-social behavior of individuals or groups in society. That was on the grounds of the premises stemming from the analysis of scientific papers and the 
systematic monitoring of this category of events by the media. ${ }^{1}$ The media, not only in Poland but all over the world, inform daily about situations when individuals, local societies, as well as the international community provide assistance to participants of events which result in fatalities or people spending the rest of their lives with disabilities. $^{2}$ Aronson et al. identify helping others in situations when such help is expected with pro-social behavior (2015, pp. 453-455). While Zimbardo and Ruch (1997, p. 548) give a selfless need to help others as an example of altruistic behavior. The Polish scientist Tadeusz Kotarbiński, describes a person that takes efficient and ethical actions in situations of threat to other people, as brave (Kotarbiński, 1987, p. 161).

The media coverage of these events makes us aware of the degree of involvement of various people from the social environment in helping victims and the injured. The message often becomes opinion-forming in the formulation of evaluations of the efficiency of intervention operations of the so-called the uniformed public services (Kałużny \& Płaczek, 2011, pp. 247-253; Kałużny, 2014, pp. 217-231; Maciejewski, 2014). However, the motives and proportions of people, who did not actively participate in the rescue operation or directly refused to help the victims and individuals or groups at risk expecting such help at the scene of the incident (Aronson, 2012, pp. 55-62; Zimbardo, 2007, pp. 323-324) are unknown. It also seems to be a difficult task to determine the proportions of those who use such extreme situations for their shameful purposes (looting, rape, escalating destruction, enjoying the destruction and suffering of others). (Zimbardo, 2007, pp. 34-44).

At this stage of the analysis, the question arises of whether the type of behavior (action) can be examined using scientific methods? Like any social phenomenon, such behavior is also the subject of research in many scientific disciplines, from sociology, through social psychology, social pedagogy, to the security sciences. The next question concerns the subjects focused on the dilemma of what to research. One of them is the etiology of pro-social and altruistic behavior (a case study), as well as cause and effect relationships between independent (socio-demographic) and dependent (problem) variables based on quantitative research (questionnaire study technique) concerning the propensity to such behavior. Conclusions and postulates of expected changes, particularly in the broadly understood education, can be formulated from research results. The development of simulation methods has resulted in scientists being able to recognize these issues in various aspects of education. The choice of methods and situations is primarily determined by the formal scientific qualifications of researchers or expert teams. Regarding the subject of the research, namely, the pro-social and altruistic behavior of military students aimed at helping people in crises, the aim of the research was specified and regarded the students' propensity to help in emergencies in various circumstances (under the influence of various factors).

\footnotetext{
1 On June 9, 2019, a serious accident occurred on the A6 road, near Szczecin. In the result of the car collision, some of the cars caught fire. Six people died. Andriy Sirotskyi, a driver from Ukraine working in Poland, risking his own life, pulled several people out of the burning cars. For this act he was hailed as our hero. More on who is Andriy Sirovatskiy? https://natemat.pl/276317,kim-jest-andrij-sirowackij-ukrai nski-kierowca-ratowal-ofiary-wypadku-na-a6?force_rwd=1 [accessed on: 12.12.2019]

2 The British "Daily Mail" describes the details of the heroic deed of 38-year-old Lukasz-a Pole, who on November 29, 2019, was the first to be told about his heroic deed. On November 29, 2019, he stood up to fight a terrorist attacking in London. The British media revealed new details about the deeds of the heroic Pole: https://fakty.interia.pl/swiat/news-brytyjskie-media-ujawniaja-nowe-szczegoly-na-temat-czynow-bo,nId,33681 97\#utm_source=paste\&utm_medium=paste\&utm_campaign=other [accessed on: 14.12.2019]
} 


\section{Materials and Methods}

The research was carried out in 2018 among military students under basic training carried out at The General Kosciuszczko Military University of Land Forces in Wroclaw. It covered 246 people ( 85 women and 161 men), randomly selected from the student population in the first year of studies of command (majors in management and command studies) of all military specialties (armored and mechanized troops, barrel and missile artillery, air defense, engineering, communications, and logistics) and medical profiles. The selection of such significantly different military specialties (command and medical) is justified on two grounds. The first one concerns the standard features of the soldier's profession and the demands placed on the profession of social trust and constitutional availability for other social groups. The second premise has the function of differentiating the commanding character of service from the medical profession (even if it concerns a military doctor). The latter must perform dual social roles concentrated within the Hippocratic Oath and a professional soldier's social model. Based on the adopted research area, further questions have arisen about specific problems. The first one concerns the differences in the propensity for pro-social and altruistic behavior among respondents representing the command-profile studies in relation to candidates for military doctors. The other one concerns the relationship between the respondents' attitudes and gender. The questions formulated imposed a need to clarify the relevant hypotheses:

1. At the beginning of the military career of candidates for professional soldiers, regardless of their military (including medical) specialties, the propensity for pro-social and altruistic behavior is mainly influenced by personality traits and environmental factors, including the process of students' primary and secondary socialization and recognized values. It is only at the stage of inculturation (acquisition of cultural features contained in the organizational culture, also related to the military specialty) that differences in pro-social and altruistic behavior emerge between future commanders and military doctors.

2. The inclination to pro-social and altruistic behavior is to a small extent related to the students' gender.

The study involved 85 women and 161 men. The average age of respondents was 20.1 years (the oldest -29 years, and the youngest -18 years old).

The method of verbal simulation using the questionnaire K-K'017, which is a modified version of the questionnaire K-K'98 (Kałużny, 2001; Kalina et al., 2005, pp. 213-218; more: Kałużny \& Kalina, 2015, pp. 221-228) was employed in the conducted research. In addition to the respondent's actions in three simulated circumstances (the threat of another person drowning, the need to help other people without a specific type and degree of danger, a dangerous road accident when the respondent is in a rush to an important meeting), the questionnaire includes nine more statements (or questions) informing about hypothetical situations with his/her participation. Six of them concerns aggression, including those targeted at the respondent, at a person close to the respondent, at a person unknown to the respondent (one time the aggression aims to deprive the victim of life, the other time the goal of physical aggression is not specified). Moreover, they are about the respondent's action in a sporting struggle, the respondent's preferred way of solving the conflict with the intention of achieving a relatively long-term effect, and the respondent's way of presenting facts to people in various life situations. Each of the twelve simulated circumstances (situations) is complemented by four alternative actions, out of which the respondent marks 
only one. He or she selects and marks the one which precisely illustrates his or her behavior in the described situations or is closest to the action the respondent would be willing to take. Three competent judges decomposed the diagnostic statements (questions) from the K-K'98 questionnaire and assessed the accuracy of the new statements using the Delphic method. Alternative actions are described in a way that a researcher familiarized with the methodology of mixed assessments should differentiate them according to the following criteria: "effective-ethical (laudable)", "ineffective—ethical (laudable)", "effectiveunethical (shameful)", "ineffective-unethical (shameful)" (Kalina \& Barczyński, 2017, pp. 187-194). All the competent judges confirmed that these criteria were met in twelve simulated descriptions of the situation (circumstances). Each criterion was assigned a numerical indicator $(3 ; 2 ; 1 ; 0$ respectively), which simplifies statistical analysis.

The reliability tests of questionnaire K-K'017 using the "test-retest" method carried out on 35 tourism and recreation students confirmed the following correlations: $r=0.869$ in the situation of "saving another person from drowning," $r=0.859$ in the situation of "the need to help other people," and $r=0.723$ when "the respondent is in a rush to an important meeting and encounters a dangerous accident on the road" (Klimczak \& Jasiński, 2019). In male students $(n=22)$ it was respectively: $r=0.882, r=0.766$, and $r=0.795$ (Kałużny $\&$ Kondzior, 2019).

In addition to the distribution of the mixed assessments in each of the three risk situations, the analysis of the research results took account of the phenomenon of stability of the declared actions, i.e., meeting identical criteria in each simulated description of the situation, e.g., "effective-ethical (brave)." The proportions of people declaring an ethical action in each simulated emergency (regardless of the expected effectiveness) were considered as a simple indicator of sacrifice. The description of both indicators: "bravery" and "dedication" were based on the data concerning all respondents, including the field of study and gender.

In the statistical analysis of empirical data, an indicator of proportions between independent sets of individual empirical variables was used. The significance of differences (in the confidence interval up to $5 \%$ ) between declared activities of independent groups was based on numerical indicators.

\section{Results}

In total, more than $95 \%$ of military students declared actions qualified as laudable in a simulated threat of drowning of another person (Table 1). Of these, about $68 \%$ declared competent and ethical actions. Competent and ethical actions are proportionally more likely to be taken by students of the command profile (74.2\%) than by medical profile students $(60.5 \%)$. The revealed difference is statistically significant at the level of confidence $p<0.05$. The activities classified as shameful are proportionally more declared by "medics", $7.9 \%$, than students of the command profile $(2.3 \%)$.

In the situation of the need to help other people, without clearly specifying type and scale of the threat, almost $89 \%$ (proportionally less than in the situation of the threat of drowning of another person) declared laudable actions. Competent and ethical actions are proportionally more likely to be taken by students of the medical profile $(57.0 \%)$ than students of the command profile (45.5\%). Although the revealed difference in the proportion of declared actions is considerable, it is not statistically significant. The activities classified as shameful were declared proportionately by more students of the 
Table 1 Proportion of military students declaring a specific mode of action in three simulated situations of random events

\begin{tabular}{|c|c|c|c|c|c|c|c|}
\hline \multirow[t]{2}{*}{ Mixed assessments } & \multicolumn{2}{|c|}{$\begin{array}{l}\text { Command profile } \\
(n=132)\end{array}$} & \multicolumn{2}{|c|}{$\begin{array}{l}\text { Medical profile } \\
(n=114)\end{array}$} & \multirow{2}{*}{$\begin{array}{l}\text { Difference } \\
\text { in proportion } \\
\%\end{array}$} & \multicolumn{2}{|c|}{ In total $(N=246)$} \\
\hline & $\mathrm{n}$ & $\%$ & $\mathrm{n}$ & $\%$ & & $\mathrm{n}$ & $\%$ \\
\hline \multicolumn{8}{|c|}{ "saving another person from drowning" } \\
\hline "effective_ethical" & 98 & 74.2 & 69 & 60.5 & $13.7^{*}$ & 167 & 67.9 \\
\hline "ineffective-ethical" & 31 & 23.5 & 36 & 31.6 & 8.1 & 67 & 27.2 \\
\hline "effective-unethical" & 1 & 0.8 & 8 & 7.0 & 6.2 & 9 & 3.7 \\
\hline "ineffective_-unethical" & 2 & 1.5 & 1 & 0.9 & 0.6 & 3 & 1.2 \\
\hline \multicolumn{8}{|c|}{ "the need to help other people" } \\
\hline "effective-ethical" & 60 & 45.5 & 65 & 57.0 & 11.5 & 125 & 50.9 \\
\hline "ineffective_ethical" & 55 & 41.7 & 38 & 33.3 & 8.4 & 93 & 37.8 \\
\hline "effective_-unethical" & 13 & 9.8 & 8 & 7.0 & 2.8 & 21 & 8.5 \\
\hline "ineffective-unethical" & 4 & 3.0 & 3 & 2.7 & 0.3 & 7 & 2.8 \\
\hline \multicolumn{8}{|c|}{ "respondent is in a rush to an important meeting and encounters a serious accident on the road" } \\
\hline "effective-ethical" & 114 & 86.4 & 91 & 79.8 & 6.6 & 205 & 83.3 \\
\hline "ineffective-ethical" & 14 & 10.6 & 15 & 13.2 & 2.6 & 29 & 11.8 \\
\hline "effective_-unethical" & 3 & 2.3 & 6 & 5.3 & 3.0 & 9 & 3.7 \\
\hline "ineffective-unethical" & 1 & 0.7 & 2 & 1.7 & 1.0 & 3 & 1.2 \\
\hline
\end{tabular}

${ }^{*} p<0.05$

$N=246$

(Pearson r-correlation coefficient $|\mathrm{r}| \leq 0.5$ at the significance level $\alpha=0.05$ )

Source: own study based on research results, Wrocław, 2019

command profile (12.8\%) than "medics," 9.7\%, which is a logical consequence of the declaration of laudable activities.

In a situation where the respondent is in a hurry to an important meeting and witnesses a dangerous road accident, more than $95 \%$ of military students declared help in the form of activities classified as commendable. In the case of a road accident of other drivers, students of the command profile $(86.4 \%)$ are proportionally more willing to act ethically and effectively than students of the medical profile (79.8\%). Conversely, there are more shameful actions taken by students of the medical profile $(7.0 \%)$ than command profile students (3.0\%).

While making a comparative analysis of the actions declared by military studentsmen and women, it should be stated that men proportionally more numerously $(70.2 \%)$ than women indicate useful and ethical actions in a simulated situation of threat of drowning of another person (Table 2). In this situation of threat, a greater number of women than men would undertake actions qualified as laudable (women 96.4\%, men 94.4\%). Conversely, proportionally less $3.6 \%$ than men $5.6 \%$ declare actions classified as disgraceful. In the system of the need to help other people, women proportionally more often than men declare competent and ethical actions, but also more frequently actions classified as laudable (women 90.6\%, men 87.6\%). Also, in this situation of threat, women less numerously declare actions considered as shameful (women 9.4\%, men 12.4\%). 
Table 2 Proportion of military students (men and women) declaring a specific mode of action in three simulated situations of random events

\begin{tabular}{|c|c|c|c|c|c|c|c|}
\hline \multirow[t]{2}{*}{ Mixed assessments } & \multicolumn{2}{|c|}{$\begin{array}{l}\text { Women } \\
(n=85)\end{array}$} & \multicolumn{2}{|c|}{$\begin{array}{l}\text { Men } \\
(n=161)\end{array}$} & \multirow{2}{*}{$\begin{array}{l}\text { Difference } \\
\text { in proportion } \\
\%\end{array}$} & \multicolumn{2}{|c|}{$\begin{array}{l}\text { In total } \\
(N=246)\end{array}$} \\
\hline & $\mathrm{n}$ & $\%$ & $\mathrm{n}$ & $\%$ & & $\mathrm{n}$ & $\%$ \\
\hline \multicolumn{8}{|c|}{ "saving another person from drowning" } \\
\hline "effective—ethical" & 54 & 63.5 & 113 & 70.2 & 6.7 & 167 & 67.9 \\
\hline "ineffective_ethical" & 28 & 32.9 & 39 & 24.2 & 8.7 & 67 & 27.2 \\
\hline "effective-unethical" & 1 & 1.2 & 8 & 5.0 & 3.8 & 9 & 3.7 \\
\hline "ineffective_-unethical" & 2 & 2.4 & 1 & 0.6 & 1.8 & 3 & 1.2 \\
\hline \multicolumn{8}{|c|}{ "the need to help other people" } \\
\hline "effective_ethical" & 50 & 58.8 & 75 & 46.6 & 12.2 & 125 & 50.9 \\
\hline "ineffective-ethical" & 27 & 31.8 & 66 & 41.0 & 9.2 & 93 & 37.8 \\
\hline "effective-unethical" & 6 & 7.0 & 15 & 9.3 & 2.3 & 21 & 8.5 \\
\hline "ineffective_-unethical" & 2 & 2.4 & 5 & 3.1 & 0.7 & 7 & 2.8 \\
\hline \multicolumn{8}{|c|}{ "respondent is in a rush to an important meeting and encounters a serious accident on the road" } \\
\hline "effective—ethical" & 68 & 80.0 & 137 & 85.2 & 5.2 & 205 & 83.3 \\
\hline "ineffective_ethical" & 12 & 14.1 & 17 & 10.5 & 3.6 & 29 & 11.8 \\
\hline "effective—unethical" & 4 & 4.7 & 5 & 3.1 & 1.6 & 9 & 3.7 \\
\hline "ineffective_-unethical" & 1 & 1.2 & 2 & 1.2 & 0.0 & 3 & 1.2 \\
\hline
\end{tabular}

$* p<0.05$

$N=246$

(Pearson r-correlation coefficient $|\mathrm{r}|=0.5$ at the significance level $\mathrm{a}=0.05$ )

Source: own study based on research results, Wroclaw 2019

In a situation when the respondent is in a rush to an important meeting and is a witness of a dangerous road accident, proportionally more men (85.2\%) declare competent and ethical assistance than women $(80.0 \%)$. Men also indicate more activities $(95.7 \%)$ qualified to be laudable than women (94.1\%). On the contrary, which is a logical consequence, activities classified as disgraceful are more frequently declared by women (5.9\%) than by men (4.3\%).

The analysis of empirical data based on the phenomenon of stability-competent and ethical actions identical in every simulated threat situation, allows the conclusion that over $30.0 \%$ of military students deserve to be called brave (Table 3). It should be noted that proportionally more people with such characteristics were revealed among students of the command profile (31.8\%) than among "medics" (28.9\%). On the other hand, people willing to selflessly help, thus sacrificing themselves for others, through actions always consistent with ethical principles, although not always capable, revealed similar proportions in both samples (almost 51\%).

The use of the indicator of the stability of actions declared by women and men, namely, competent and ethical actions, which are identical in each of the simulated threat situations (Table 4), enables the conclusion that proportionally there are more brave women $(35.3 \%)$ than men $(27.9 \%)$. On the contrary, more people willing to selflessly help and sacrifice for others were revealed in the male sample (53.4\%) than in the female sample (45.9\%). Given the total of useful and ethical measures (bravery) and ethical, although not always competent (sacrifice), the proportions of women and men are comparable (respectively: $81.2 \%$ and $81.3 \%$ ). 
Table 3 Proportions of military students whose actions testify to "bravery" and "sacrifice"

\begin{tabular}{|c|c|c|c|c|c|c|c|}
\hline \multirow[t]{2}{*}{ Mixed assessments } & \multicolumn{2}{|c|}{$\begin{array}{l}\text { Command pro- } \\
\text { file }(n=132)\end{array}$} & \multicolumn{2}{|c|}{$\begin{array}{l}\text { Medical profile } \\
(n=114)\end{array}$} & \multirow{2}{*}{$\begin{array}{l}\text { Difference } \\
\text { in proportion } \\
\%\end{array}$} & \multicolumn{2}{|c|}{$\begin{array}{l}\text { In total } \\
(N=246)\end{array}$} \\
\hline & $\mathrm{n}$ & $\%$ & $\mathrm{n}$ & $\%$ & & $\mathrm{n}$ & $\%$ \\
\hline \multicolumn{8}{|l|}{ "bravery" } \\
\hline $\begin{array}{l}\text { "effective_ethical" } \\
\text { "sacrifice" }\end{array}$ & 42 & 31.8 & 33 & 28.9 & 2.9 & 75 & 30.5 \\
\hline "ethical - effective, ineffective" & 67 & 50.7 & 58 & 50.9 & 0.2 & 125 & 50.8 \\
\hline
\end{tabular}

* $p<0.05$

$N=246$

(Pearson r-correlation coefficient $|\mathrm{r}| \leq 0.5$ at the significance level $\alpha=0.05$ )

Source: own study based on research results, Wrocław, 2019

\section{Discussion}

The results were analyzed in relation to the three empirical questions selected from the questionnaire K-K'017. The rationale for the choice is the fact that each year thousands of people lose their lives or suffer severe injuries in accidents on the roads, in water bodies, or any other circumstances. Although in Europe, in recent years the number of road accident fatalities has decreased by about $57 \%$, in Poland only by $6 \%$. In 2017, Sweden, Great Britain, and the Netherlands were the European Union Member States with the best results in terms of road safety. The countries with the highest mortality rate included Romania, Bulgaria, Croatia, and Poland (SŚnDUE, 2019). In Poland, 31,674 road accidents were reported to the Police in 2018, and, compared to 2017, the number dropped by $3.3 \%$. As a result, 2,862 people died. There was a decrease in the number of accidents, but the number of deaths increased by $1.1 \%$ (Symon, 2019, p. 6).

In Poland, another significant threat is drowning. It is a fact that the activity of people in the basins is seasonal (June-September) due to climatic conditions, and yet the risk of drowning is twice as high as in other EU countries. For every 100 thousand inhabitants in

Table 4 Proportion of military students-men and women, whose actions testify to "bravery" and "sacrifice"

\begin{tabular}{|c|c|c|c|c|c|c|c|}
\hline \multirow[t]{2}{*}{ Mixed assessments } & \multicolumn{2}{|c|}{$\begin{array}{l}\text { Women } \\
(n=85)\end{array}$} & \multicolumn{2}{|c|}{$\begin{array}{l}\text { Men } \\
(n=161)\end{array}$} & \multirow{2}{*}{$\begin{array}{l}\text { Difference } \\
\text { in proportion } \\
\%\end{array}$} & \multicolumn{2}{|c|}{$\begin{array}{l}\text { In total } \\
(N=246)\end{array}$} \\
\hline & $\mathrm{n}$ & $\%$ & $\mathrm{n}$ & $\%$ & & $\mathrm{n}$ & $\%$ \\
\hline \multicolumn{8}{|l|}{ "bravery" } \\
\hline $\begin{array}{l}\text { "effective_ethical" } \\
\text { "sacrifice" }\end{array}$ & 30 & 35.3 & 45 & 27.9 & 7.4 & 75 & 30.5 \\
\hline "ethical - effective, ineffective" & 39 & 45.9 & 86 & 53.4 & 7.5 & 125 & 50.8 \\
\hline
\end{tabular}

${ }^{*} p<0.05$

$N=246$

(Pearson r-correlation coefficient $|\mathrm{r}| \leq 0.5$ at the significance level $\alpha=0.05$ )

Source: own study based on research results, Wrocław 2019 
Poland, two people die in water, while in Europe-one person on average. In Poland, 457 people drowned in 2017, while in 2018, 545 people died in water. The most frequent causes of drowning—bravado and alcohol—remain unchanged for years (Police Statistics, 2019).

Based on the results of the research, a conclusion emerges that these three situations, despite two specificities (road accident, drowning person), refer to a wide range of circumstances in which there is a need to help others. Calling part of these verbal simulations circumstances is justified to a general extent by the crisis being described. An overall wording of the need to help others is capacious and can refer to an extreme situation where there is a high risk of loss of life or health for the person providing help. Such a risk concerns not only people who are accidentally involved in the threat and are willing to help but also the personnel of uni-formed public services (e.g., rescuers, firefighters, police officers, soldiersincluding soldiers - physicians). It is evident that a specific category of situations commonly regarded as difficult and dangerous are not such for the specialists mentioned above. However, the professional preparation and even many years of service in uniformed public services will not compensate for factors that modify the behavior, or actions (that is, conscious behavior) of specific people in given situations.

Probably one of the best known is the experiment from the seventies of the previous century, which shows the power of specific circumstances to modify the actions of people. John Darley and Daniel Batson observed 40 volunteer students preparing for pastoral work at the Princeton Theological Seminary. The research was officially about religious education and vocation to the clergy. After the instruction was received in one building, the students moved to another building to preach, some of which was about the parable of the merciful Samaritan (St. Luke's Gospel, Chapter X). Before each student went out to the second building to give his speech (sermon), the experimenters systemically manipulated his belief in how much time he had to get there. In the gate, there was a man (the experimenters' assistant) lying, coughing, moaning, with his head on the ground and eyes closed. There was an opportunity to become the Good Samaritan. In total, $60 \%$ of the observed students did not stop to help. On average, $63 \%$ of those not in a rush, $45 \%$ of those hurrying, and only $10 \%$ of the students who were late pro-vided assistance (Darley \& Batson, 1973, pp. 100-108).

Although almost half a century has passed, today, there is another society, the era of electronic media, as well as other research tools (direct, indirect observation), and yet the results of the research under discussion warrant conclusions about the similarity of social sensitivity to the need to help people at risk. Notwithstanding the gender, more than $81 \%$ of students are characterized by the nobility of deeds-bravery and sacrifice. In each of the three simulated situations of danger, $30.5 \%$ of students demonstrated signs of bravery, i.e., competent and ethical actions. The study revealed proportionally more brave people among students of command profile (31.8\%) than students of the medical profile $(28.9 \%)$, with more females (35.3\%) than male students $(27.9 \%)$. Every third military student (regardless of their field of study) is not susceptible to situational factors that would result in abandoning the social mission of helping others in need. As the research shows, in every situation of threats, they are prone to take action that results in consequences and, at the same time, complies with the ethical standards in force. The components of bravery-efficiency of action, nobleness of purpose, and personal sacrifice - have been proportionately more demonstrated by women than men.

The analysis of empirical data also shows that proportionally more people declaring un-ethical actions in simulated emergencies are among students of medical profile $(8.2 \%$ on average) than students of command profile (5.8\% on average). Comparing the declared actions of women and men, we can state that in the sample of women, we revealed proportionally less $(6.3 \%$ on average) unethical actions in simulated threat situations than in the sample 
of men (7.4\% on average). The results of the research give us arguments to conclude that women are better both mentally and efficiently prepared than men to deal effectively with various situations threatening other people. That is probably due to the gender egalitarianism associated with the cultural change taking place in Polish society for 30 years. It has a twofold etiology. The first is trends in modern societies, which place women on an equal footing with men in almost all social roles. The other one concerns instrumental values, the guarantee of a dignified life, independence, and professional stability, which are fundamental motivators for improving one's qualifications, and gaining a higher position and respect in a market economy (Inglehart \& Norris, 2009). Both have a common denominator, namely, the increasing tendency of women to succeed in different contexts of working life and the environment's expectations. That trend is also related to the typology of cultures based on Geert Hofstede's four dimensions. His theory identifies women as more effective in achieving their goals, willing to compromise, calm, and valuing education and qualifications (Hofstede, Hofstede \& Minkov, 2011).

Based on the phenomenon of the stability of the declared actions, it should be stated that in the process of recruiting for military studies, a proportionately large number (over $81 \%$ ) of students with the characteristics of noble and courageous individuals was obtained. People who are ready to selflessly help others in the way they are able, regardless of their own risk. Another crucial issue is that more than $30 \%$ of students will take competent and ethical action regardless of the threat. In their unselfish commitment and action for the benefit of another person, these young people deserve the highest respect and social recognition.

The findings of the carried-out research are so important that they concern candidates for military service, additionally starting their military career and "charged" with values acquired in civil life. Thus, it covers people preparing for a profession that enjoys high de facto prestige in every society, but also a profession with a higher than average level of risk. Moreover, a person's declared anonymous actions, made voluntarily in situations of simulated threats, are a premise for conclusions about his or her intentions and attitudes, as well as ways of behaving in other similar, real circumstances. However, it is difficult not to agree with P. Bourdieu, that the source of most human actions are not intentions but acquired dispositions (Bourdieu, 2009, p. 136).

\section{Summary}

Pro-social and altruistic activities in the modern world burdened with the stigma of consumerism, the rush for career and social position, have become scarce but also unfashionable "commodity." The disappearance of the inclination to behaviors under consideration, particularly in the face of the threat of losing one's health and life, is visible among the representatives of the young generation of people who build their own identity on instrumental rather than autotelic values. That means that the tendency to help others, generosity, sacrifice, and heroism ceases to be a value and reduces social capital through the disappearance of trust among people, social anomy and pure callousness. Based on the observation of antisocial phenomena among people (especially those representing modern societies), a general question has emerged about the scale of the phenomenon and its structure concerning various social classes and social strata as well as occupational groups.

By adopting the criterion of social availability (the constitutional obligation to fulfill tasks for the security of the state and its citizens) of certain professional groups, such as the military, a dilemma arose as to whether young people's negative behaviors also affect the occupational groups. The results of the research conducted indicate that altruistic and pro-social behavior among candidates for soldiers, especially the youngest ones, is related 
to primary and secondary education and socialization, which may prove that environmental factors should be significant in the process of recruitment and verification of candidates for service. That justifies the specificity of the service and the subsequent stages of adaptation to it, where qualities such as ethics and bravery in correlation with effectiveness are essential. More specifically, the research results indicate that:

- taking competent and ethical action in situations of danger to other people depends on the physical and mental predisposition of the person concerned;

- in the process of recruitment for military studies, a positive selection of students takes place with the efficiency and ethical dispositions taken into consideration;

- women, proportionally more numerous than men, are distinguished by the components of bravery in situations of threat to other people;

- over $30 \%$ of first year military students reveal features of brave people and about $51 \%$ are characterized by ethical values revealing disinterested sacrifice for the benefit of others.

In conclusion, it is vital to raise the issue contained in the first specific hypothesis. It assumes that at the beginning of the military career of candidates for professional soldiers, the tendency to behave in a pro-social and altruistic way is not related to the chosen military specialty but only to students' personality traits and the process of their primary and secondary socialization, including recognized values. In order to operationalize the second part of the hypothesis, it was assumed a priori that the formation of specific values for both studied candidate groups is created in subsequent phases of adaptation to military service, within the framework of inculturation, i.e., the acquisition of cultural traits included in the culture not only of the organization but also in the culture of the military "specialty." It should be stressed that at each educational stage, both education profiles reveal significant cultural differences related to the specificity of tasks performed by the soldier-commander and the soldier-doctor. The issue should be treated as a critical direction of further research on pro-social and altruistic behavior and broadly understood values. The research outcomes presented in this article should be considered a seed and, at the same time, a pilot for crosssectional research of an evaluation nature based on many other independent variables specific to the military, such as military specialty related to the tasks performed.

Another direction of research on axiological aspects of military service is related to the internationalization of military education at Polish military universities. The studies focused on cultural differences between Polish military students and students from countries such as Saudi Arabia, Qatar, and Kuwait, which are unfortunately burdened with limitations of a formal nature (consent of home countries), appear exceptionally interesting.

Funding Ministry of National Defense of Poland (statutory research of the University no 105/WZA/58/ $\mathrm{DzS})$.

\section{Declarations}

Ethical Approval All procedures performed in studies involving human participants were in accordance with the ethical standards of the institutional and/or national research committee and with the 1964 Helsinki declaration and its later amendments or comparable ethical standards.

Informed Consent Informed consent was obtained from all individual participants included in the study. 


\section{References}

Annas, J. (2015). Virtue and Heroism (p. 23). The Lindley Lecture: The University of Kansas, October.

Aronson, E. J. (2012). Człowiek istota społeczna. Warszawa: Wyd. Naukowe PWN.

Aronson, E., Wilson, T. D., Akert, R. M., \& Sommers, S. R. (2015). Social psychology. The Heart and the Mind (9th ed.). New York: Prentice Hall.

Batson, C. D., \& Powell, A. A. (2003). Altruism and pro-social behaviour. In T. Million \& M. J. Lerner \& I. B. Weiner (Ed.), Handbook of Psychology, Vol. 5: 463-484. New Jersey: John Wiley and Sons Inc.

Batson, C. D., \& Shaw, L. L. (1991). Evidence for altruism: Toward a pluralism of pro-social motives. Psychological Inquiry, 2(2), 107-122.

Batson, C. D., \& Ahmad N. Y. (2009), Altruism and Prosocial Behavior in Groups, Emerald Group Publishing Limited.

Batson, C. D., Batson, J. G., Todd, R. M., Brummett, B. H., Shaw, L. L., \& Aldeguer, C. M. R. (1995). Empathy and the collective good: Caring for one of the others in a social dilemma. Journal of Personality and Social Psychology, 68(4), 619-631.

Blechman, E.A. (2002). Altruism, In N. J. Salkind (ed.), Child Development, New York.

Bodziany, M. (2019). Wewnętrzne uwarunkowania bezpieczeństwa kulturowego Polski. Wrocław: Wyd. AWL.

Bodziany M. (2021). The COVID-19 Pandemic and the Effectiveness Of Education In Mili-tary Universities In Poland, in: Anna Visvizi, Linda Daniela ed., Challenges On Distance Education, Routledge - manuscript in the process of publishing.

Bourdieu, P. (2009). Rozum praktyczny. O teorii działania, Kraków: Wyd. Uniwersytetu Jagiellońskiego.

Brytyjskie media ujawniają nowe szczegóły na temat czynów bohaterskiego Polaka https://fakty.interia.pl/swiat/ news-brytyjskie-media-ujawniaja-nowe-szczegoly-na-temat-czynow-bo,nId,3368197\#utm_source= paste\&utm_medium=paste\&utm_campaign=other (12.12.2019).

Chopra, Y. (1963). Professor Urmson on 'saints and Heroes.' Philosophy, 38(144), 160-166.

Darley, J. M., \& Batson, C. D. (1973). From Jerusalem to Jericho: A study of situational and dispositional variables in helping behavior. Journal of Personality and Social Psychology, nr, 27, 100-108.

Davies, Ch. (1989). Goffman's Concept of the Total Institution: Criticisms and Revisions. Human Studies, Vol. 12, No. 1/2, Erving Goffman's Sociology (Jun), p. 77-95.

Dudek, Z. W. (2007). Archetypowe wzorce inicjacji bohaterskich. Albo Albo, nr, 3, 10.

Eisenberg, N., \& Fabes, R. A. (1990). Empathy: Conceptualization, measurement, and relation to pro-social behawior. Motivation and Emotion, 14(2), 131-149.

Franco, Z. E., Efthimiou, O., \& Zimbardo, F. G. (2016) Heroism and Eudaimonia: Sublime Actualization Through the Embodiment of Virtue, In: J. Vitters $\varnothing$ (ed.), Handbook of Eudaimonic Well-Being, International Handbooks of Quality-of-Life, Project: Heroism, Springer International Publishing Switzerland 337-348.

Goffman, E. (1975). Charakterystyka instytucji totalnych. In J. Szacki (ed.), Elementy teorii socjologicznych, PWN, Warszawa.

Goethals, G. R., \& Allison, S. T. (2012), Making Heroes: The Construction of Courage, Competence, and Virtue, In Advances in Experimental Social Psychology, edited by J. M. Olson and M. P. Zanna, 183-235. Vol. 46. San Diego: Elsevier.

Hofstede, G. J., Hofstede, G., \& Minkov, M. (2011). Kultury i organizacje. Warszawa: PWE.

Inglehart, R., \& Norris, P. (2009). Wzbierajaca fala: równouprawnienie płci a zmiana kulturowa na świecie; przet. Beata Hellmann, Warszawa: PIW.

Kalina, R. M., \& Barczyński, B. J. (2017). Mixed assessments as mental and pedagogic basis of innovative selfdefence. Archives of Budo, nr, 13, 187-194.

Kalina, R. M., Dadeło, S., \& Chodała, A. (2005). Declared bravery and its measurement. Physical Education and Sport, 49(3), 213-218.

Kałużny, R. (2001). Wykształcenie i nabyte doświadczenia jako kryterium przewidywania sposobów działań człowieka w sytuacjach zagrożen, Opole: Uniwersytet Opolski. (doctor paper - manuskript).

Kałużny, R. (2014). Idea dzielności w stużbie funkcjonariuszy grup dyspozycyjno-mundurowych. In P. Bogdalski, D. Bukowiecka, R. Częścik, B. Zdrodowski (ed.), Grupy dyspozycyjne społeczeństwa w świetle potrzeb bezpieczeństwa państwa, Szczytno: Wyd. Wyższej Szkoły Policji w Szczytnie, vol. 1, pp. 217-231.

Kałużny, R., \& Kalina, G. (2015). Change of the actions declared in simulated situations involving interpersonal aggression. Arch Budo Sci Martial Art Extreme Sport, nr, 11, 221-228.

Kałużny, R., \& Kondzior, E. (2019). Reliability of the KK'017 questionnaire - test-retest military cadets, Arch Budo Sci Martial Art Extreme Sport, nr 15.

Kałużny, R., \& Płaczek, A. (2011). Declared bravery of Polish police officers (comparative studies of 1998 and 2010). Archives of Budo, 7(4), 247-253. 
Kaptein, M. (2008). Developing and testing a measure for the ethical culture of organizations: The corporate ethical virtues model. Journal of Organizational Behavior, 29(7), 923-947.

Kaur, R. (2019). A Review on Prosocial Behavior: Social Psychology, International Journal of Research in Engineering, IT and Social Sciences, 9(1), 227-229.

Klimczak, J., \& Jasiński, T. (2019). Empirical verification of reliability and accuracy of the KK'017 questionnaire, Arch Budo Sci Martial Art Extreme Sport, nr 15.

KodekshonorowyżołnierzazawodowegoWojskaPolskiego,https://antykorupcja.gov.pl/ak/import/kodeksy-etyczne/ 3581,Kodeks-honorowy-zolnierza-zawodowego-Wojska-Polskiego.html (01.03.2020).

Kotarbiński, T. (1987). Pisma etyczne. Wrocław-Łódź: Zakład Narodowy im. Ossolińskich.

[KHŻWP] Kodeks Honorowy Żotnierza Zawodowego Wojska Polskiego, https://archiwum2019.mon.gov.p1/ dokumenty/ (02.02.2020)

Łobocki, M. (1999). Abc wychowania. Lublin: Wyd. UMCS.

Łobocki, M. (2006). Teoria wychowania w zarysie. Kraków: Wyd. IMPULS.

Maciejewski, J. (2014). Grupy dyspozycyjne. Analiza socjologiczna. Wrocław: Wyd. Uniwersytetu Wrocławskiego.

New, Ch. (1974). Saints Heroes and Utilitarians. Philosophy, 49(188), 179-189.

Quain, S., Yidana, X., Ambotumah, D., \& Mensah-Livivnstone, B.B. I.J.N.A. (2016). Pro-social Behavior amongst Students of Tertiary Institutions: An Explorative and a Quantitative approach Journal of Education and Practice, 7(9), 26-33

Penner, J. F., Dovidio, J. A., Piliavin, \& Schroeder, D. A. (2005). Pro-social behavior: multilevel perspectives. Annual Review of Psychology, 56, 365-392.

Police statistic $=$ Statystyka Policji, http://statystyka.policja.pl/st/wybrane-statystyki/utoniecia (15.12.2019r.)

Pybus, E. M. (1982). Saints and Heroes. Philosophy, 57(220), 193-199.

[SŚnDUE] (2019). Statystyki śmiertelności na drogach w UE (infografika), https://www.europarl.europa.eu/news/ pl/headlines/society/20190410STO36615/statystyki-smiertelnosci-na-drogach-w-ue-infografika

Symon, E. (2019). Wypadki drogowe w Polsce w 2018 roku. Warszawa: Wyd. Biuro Ruchu Drogowego Komendy Głównej Policji.

Tarasiewicz, P. (2010). Bohater a naród. Cywilizacja, 35(2010), 48-59.

Wardzała-Kordyś, J., \& Bodziany, M. (2012), From the Ethos of Chivalry to Regular Soldier's Code of Honour. Selected Historical, Sociological and Legal Aspects. In H. Spustek (ed.), Obywatel w mundurze. Aksjologiczny wymiar funkcjonowania nowoczesnych sit zbrojnych, Wrocław: Wyd. WSOWL, Wrocław, pp. 246-259.

Zimbardo, P. G. (2007a). The heroic imagination: A talk with Phil Zimbardo. Retrieved from http://www.edge. org/3rd_culture/zimbardo07/zimbardo07_index.html (12.01.2020)

Zimbardo, P.G., \& Ruch, F.L. (1997). Psychology and life. Glenview: Scott, Foresman and Company, Illinois: United States of America.

Publisher's Note Springer Nature remains neutral with regard to jurisdictional claims in published maps and institutional affiliations. 